\section{IJ§ER}

ISSN: 2149-5939
International Journal of Social Sciences and Education Research

Online, http://dergipark.gov.tr/ijsser

Volume: 1(3), 2015

\title{
Analyzing the prosocial behaviors of pre-school children in accordance with teacher's point of view
}

\author{
Hilal Karoğlu ${ }^{1} \quad$ Perihan Ünüvar ${ }^{2}$
}

Received Date: 01 / 04 / $2015 \quad$ Accepted Date: 01 / 07 / 2015

\begin{abstract}
This study has been carried out in order to determine the prosocial behaviors of pre-school children. Prosocial behaviors have been analyzed under four categories as cooperation, sharing, collaboration and consolation. This research is a qualitative research having the quality of a descriptive survey model. Teacher interview form has been used as data collection instrument. Working group of this research includes 30 pre-school teachers who work in pre-school education institutions. Research data has been analyzed by using content analysis method. Main titles have been determined by the researcher within the frame of the limitations of the research. Frequency and percentage tables have been created regarding pro-social behaviors under each title. Findings of this research indicate that the most frequent cooperation behavior of the children is to help their friends in putting on or taking out their coats, cardigans or shoes. It also indicates that students generally share their paintings, play dough and toys with their friends; they collaborate while they tidy up their class. Children frequently go up to their friends when they are sad/crying as a consolation behavior.
\end{abstract}

Keywords: Prosocial, early childhood, social development

\section{Introduction}

Razon defines the preschool period, the first six years of life as an important period in which the physical, mental and emotional growth of the child is rapid, the personality structure begins to form and the basic habits are acquired (Dinç and Gültekin, 2003). Nowadays, in order to be "successful" academically or in daily life, having various social skills is as necessary as cognitive abilities and talents (Özdemir and others, 2012). Prosocial behaviors form a part of the social skills. Motowidlo and Brief define prosocial behaviors as acts carried out with the hope of providing benefit to the others (İpek, 2014). According to Eisenberg and Mussen, "Prosocial behaviors" are voluntary actions with the aim of helping or providing benefit to other individuals or groups (Kahraman, 2012). Olweus and friends have defined the acts of consoling unhappy people (comforting), helping, sharing and cooperating as types of prosocial behaviors (Uzmen, 2001). Hastings, Utendale and Sullivan have valued positive behaviors such as sharing, comforting, rescuing, fairness, justness, friendship and blood \& organ donation within the scope of prosocial behaviors. (Ayten, 2009). The concept of prosocial behavior indicates the "positive social behaviors" displayed by individuals without any expectation of reward or punishment. According to Carsaro, Johnson, Christie and Yawkey, preschoolers socialize by acquiring skills such as sharing, getting in line, cooperating, accepting the point of view of others and preventing aggression during the social development period (Avcioğlu, 2003). These skills are highly important in order to have a

\footnotetext{
${ }^{1}$ Research Assistant, Bayburt University, Education Faculty Primary Education Department, Early Childhood Education Program, BAYBURT/TURKEY, hkaroglu@bayburt.edu.tr

${ }^{2}$ Assoc. Prof. Mehmet Akif Ersoy University, Education Faculty Primary Education Department, Early Childhood Education Program, BURDUR/TURKEY, perihanunuvar@mehmetakif.edu.tr
} 
Karoğlu, H., Ünüvar, P. (2015). Analyzing the prosocial behaviors of pre-school children in accordance with teacher's point of view. International Journal of Social Sciences and Education Research, 1 (3), 692-698.

society that consists of individuals with healthy communication skills and capable of respecting each other. Developing positive social behaviors from the preschool period is important in creating a more qualified society. Determining the type of activities that lead children towards positive social behaviors will provide benefit to the environmental preparation process for such behaviors and the parents' and teachers' support regarding these behaviors. Therefore, in this research, the types of positive social behaviors within the scope of preschool education activities have been determined. In accordance with this purpose, issues such as the distribution of prosocial behaviors displayed by preschoolers according to the activities, the behaviors displayed in those activities, the definition of helping, sharing, cooperative and comforting behaviors have been studied in this research.

\section{Method}

This research is a qualitative research in which the descriptive survey model has been used. The study group of this research consists of 30 preschool teachers working in preschool education institutions. 13 of them work in the nursery class of elementary schools, while 17 of them work in independent kindergartens. 9 teachers work with four year old children, 13 with five year old children and 8 with six year old children. 24 of them work in the city or county center, while 6 of them work in the village. The teacher interview form has been used as the data collection tool. The form has been created with two sections; information regarding the institution which includes topics regarding the location, the institution and the age of the group that the teacher is working with, and the opinions about the prosocial behaviors (helping, sharing, cooperative and comforting) are collected in the other section. An expert opinion has been consulted for the appearance and the content validity of the interview form. For the external validity of the data, the interview information has been recorded in forms and the results are divided into categories and sub-categories authentically. (Elo and Kyngas, 2008). To provide analysis reliability, the raw data in the interview forms have been categorized and digitized independently by two different researchers, thus a reliability based on observation has been established (Yıldırım and Şimşek, 2011). The data of the research have been analyzed using the content analysis method. The behaviors have been grouped considering the basic sections within the daily education flow in preschool education. Frequency tables have been formed regarding the prosocial behaviors below every title and also, direct quotations have been included.

\section{Findings}

3.1. The findings regarding the distribution of prosocial behaviors displayed by preschoolers have been given in Table 1.

Table 1. The general distribution of prosocial behaviors according to activities

\begin{tabular}{lccccc}
\hline Activity & Helping & Sharing & Cooperative & Comforting & Total \\
\hline $\begin{array}{l}\text { Arrival at school - } \\
\text { Playtime }\end{array}$ & 14 & 23 & 7 & 40 & 84 \\
$\begin{array}{l}\text { Tidying up - cleaning } \\
\text { Integrated group (older - }\end{array}$ & 8 & 0 & 16 & 0 & 24 \\
younger) & 16 & 26 & 18 & 11 & 71 \\
Lunchtime & 4 & 21 & 0 & 51 & 204 \\
\hline Total & 42 & 70 & 41 & & 25 \\
\hline
\end{tabular}


Karoğlu, H., Ünüvar, P. (2015). Analyzing the prosocial behaviors of pre-school children in accordance with teacher's point of view. International Journal of Social Sciences and Education Research, 1 (3), 692-698.

According to the data obtained from the teachers, it is seen in Table 1 that the children display positive social behaviors mostly during the arrival at school and playtime activities (84). It is then followed by integrated older - younger group activities. Prosocial behaviors are seen fewest during the tidying up - cleaning and lunchtime activities. The prosocial behaviors displayed by children are respectively sharing (70), comforting (51), helping (42) and cooperative (41).

\subsection{Findings regarding the helping behaviors displayed by preschoolers}

Table 2. Helping behaviors displayed by preschoolers $(\mathrm{N}=30)$

\begin{tabular}{lll}
\hline $\begin{array}{l}\text { Activity in which the behavior } \\
\text { was displayed }\end{array}$ & Helping Behaviors & f \\
\hline \multirow{2}{*}{ Arrival at school - Playtime activ- } & 1. Wearing \& taking off coat/cardigan & 9 \\
ities (14) & 2. Wearing \& taking off shoes & 3 \\
\hline Tidying up - cleaning activities & 1. Helping the inclusive student & 2 \\
\hline (8) & 2. Morganizing chairs & 4 \\
& 3. Tidying up locker & 3 \\
\hline & 1. Helping a student with an incomplete work & 1 \\
\hline \multirow{2}{*}{ Integrated group (older - } & 2. Cut - paste (art activity) & 10 \\
younger) activities (16) & 3. Singing/reading a poem & 3 \\
& 4. Reading-writing, line completing & 1 \\
\hline Lunchtime activities (4) & 5. Completing a painting & 1 \\
\hline
\end{tabular}

According to the opinion of the teachers, the children display the helping behaviors more within the integrated group (older - younger) and arrival at school - playtime activities. Helping behaviors are seen less during the lunchtime activities. The kids respectively help the other kids finish their work, wear or take off coat/cardigan and rearrange the chairs.

Examples from the teachers' statements:

“...During lunchtime, they are helping out other friends in need..." (Ex1, county center, elementary school nursery class, group of 4 year olds)

"...During the activity, they are helping out their friends who have difficulty finishing their activities" (Ex9, county center, independent kindergarten, group of 5 year olds)

"... I have an inclusive student. They are helping him adapt to the class rules. They take his hand and take him to the playground because he is shy about it." (Ex11, county center, independent kindergarten, group of 4 year olds)

\subsection{Findings regarding the sharing behaviors displayed by preschoolers}

Children display sharing behaviors in similar amounts within integrated group (older younger) activities, arrival at school - playtime activities and lunchtime activities. The kids mostly share their food. It is seen in Table 3 that afterwards comes sharing the toys in the classroom and the painting materials that they use during the activities. 
Karoğlu, H., Ünüvar, P. (2015). Analyzing the prosocial behaviors of pre-school children in accordance with teacher's point of view. International Journal of Social Sciences and Education Research, 1 (3), 692-698.

Table 3. The sharing behaviors displayed by the preschoolers $(\mathrm{N}=30)$

\begin{tabular}{|c|c|c|}
\hline $\begin{array}{l}\text { The activity in which the behavior has been } \\
\text { displayed }\end{array}$ & Sharing Behaviors & $\mathrm{f}$ \\
\hline \multirow{2}{*}{ Arrival at school - Playtime activities (23) } & 1. Sharing the toys in the classroom & 18 \\
\hline & 2. Sharing personal toys & 5 \\
\hline Lunchtime activities (21) & 1. Sharing lunch/meal & 21 \\
\hline \multirow{4}{*}{$\begin{array}{l}\text { Integrated group (older - younger) activity } \\
\text { (26) }\end{array}$} & 1. Sharing paint & 18 \\
\hline & 2. Sharing silly putty & 6 \\
\hline & $\begin{array}{l}\text { 3.Sharing a recently learned infor- } \\
\text { mation }\end{array}$ & 1 \\
\hline & 4. Sharing feelings/thoughts & 1 \\
\hline
\end{tabular}

Examples from the teachers' statements:

"..., the most easily shared things are the paints that they use. They also share silly putties." (Ex3, county center, independent kindergarten, group of 4 year olds)

"....They share and play with the toys that they bring from home in toy days. They also share their food during lunchtime” (Ex16, county center, elementary school nursery class, group of 5 year olds)

“...They split and share their food with their friends who have a missing ingredient in the nutrition list." (Ex15, county center, elementary school nursery class, group of 5 year olds)

\subsection{Findings regarding the cooperative behaviors displayed by preschoolers}

Table 4. The cooperative behaviors displayed by the preschoolers

\begin{tabular}{lll}
\hline The activity in which the behavior has been displayed & Behaviors & $\mathrm{f}$ \\
\multirow{2}{*}{ Arrival at school - Playtime activities (7) } & 1.Building towers with blocks & 4 \\
& 2.Setting up games & 3 \\
\hline \multirow{2}{*}{ Tidying up - cleaning activities (16) } & 1. Tidying up the classroom & 13 \\
& 2.Cleaning the classroom & 3 \\
\hline \multirow{2}{*}{ Integrated group (older - younger) activity (18) } & 1.Playing & 11 \\
& 2.Group projects & 7 \\
\hline
\end{tabular}

It is seen in Table 4 that the kids display cooperative behaviors respectively during integrated group (older - younger) activity, tidying up/cleaning activities and arrival at school - playtime activities. The children mostly display cooperative behaviors during tidying up the classroom, playing and carrying out group projects.

\section{Examples from the teachers' statements:}

"...They are usually cooperating during their free time. I can observe such behaviors while they play, build towers with blocks, and sometimes during the group projects..." (Ex2, county center, independent kindergarten, group of 4 year olds)

"...I can observe them cooperating while preparing for the games, tidying up the classroom." (Ex30, county center, elementary school nursery class, group of 5 year olds)

\subsection{Findings regarding the comforting behaviors displayed by preschoolers}

It is seen in Table 5 that the kids usually display comforting behaviors during the arrival at school and playtime activities. The children mostly display the comforting behavior by approaching to the sad/crying friend and verbally consoling him. Giving toys in order to console is the least preferred option. 
Karoğlu, H., Ünüvar, P. (2015). Analyzing the prosocial behaviors of pre-school children in accordance with teacher's point of view. International Journal of Social Sciences and Education Research, 1 (3), 692-698.

Table 5. The comforting behaviors displayed by the preschoolers

\begin{tabular}{|c|c|c|}
\hline $\begin{array}{l}\text { The activity in which the behav- } \\
\text { ior has been displayed }\end{array}$ & Behaviors & $\mathrm{f}$ \\
\hline \multirow{5}{*}{$\begin{array}{l}\text { Arrival at school - Playtime activ- } \\
\text { ities (40) }\end{array}$} & 1.Approacing to a sad/crying friend & 13 \\
\hline & 2.Verbally consoling a sad/crying friend & 12 \\
\hline & 3.Consoling a friend who misses his parents & 6 \\
\hline & 4.Kissing/hugging an ill friend & 5 \\
\hline & 5.Giving gifts/objects/toys & 4 \\
\hline \multirow{2}{*}{ Integrated group activity (11) } & 1.Toucing to the back/hugging/holding hands with a sad friend & 6 \\
\hline & 2. Picking up a fallen friend & 5 \\
\hline
\end{tabular}

Examples from the teachers' statements:

"...He says "this is a game, you can win and you can lose" to a friend who has lost a competition and crying." (Ex29, county center, elementary school nursery class, group of 6 year olds)

"....They pick up a friend who has fallen while playing a game by holding his hand, they try to console their crying friends by approaching them during the first days of school..." (Ex12, county center, independent kindergarten, group of 4 year olds)

“..Addressing a friend who hadn't brought (forgotten) his toy for the toys day saying -don't be upset, you can play with my toy-..." (Ex7, county center, independent kindergarten, group of 5 year olds)

\section{Debate and conclusion}

The findings obtained from this research show that preschoolers mostly display prosocial behaviors during the arrival at school and playtime activities. The prosocial behaviors displayed during the integrated older/younger group activities come second. Prosocial behaviors are least displayed during tidying up/cleaning and lunchtime activities. Arrival at school and playtime activities consist of activities that the kids direct according to their preferences and choices. They are hours in which the children interact with each other comfortably with the least amount of direction and guidance by the teachers. For this reason, arrival at school and playtime hours might be the most productive hours in terms of prosocial behaviors. Other activities are usually carried out with guidance and under teacher control during the daily education flow. The prosocial behaviors might have been observed less due to the level of comfort that the kids feel to act as they like. Hence, Özyürek and Aydoğan (2011), in their research regarding the teacher applications in free time activities, have obtained the finding that the teachers care more about what the children want during the free time activities.

Children mostly display sharing and comforting behaviors, and display cooperative and helping behaviors less. Sharing and comforting behaviors are behaviors which can emerge more easily during arrival at school and playtime activities. Helping and cooperative behaviors are more easily displayed during desk activities, tidying up and cleaning time. This result is consistent with the finding which shows that prosocial behaviors are mostly displayed during arrival at school and playtime activities. The research carried out by Kakavoulis (1998) showed that the comforting and cooperative behaviors are displayed more than the sharing and helping behaviors by younger children. The results obtained from our research partially correspond with the results obtained from Kakavoulis (1998)' results. Uzmen (2001), in a research regarding four books with the content of helping, and four books with the content of sharing behaviors, found out that reading these 
Karoğlu, H., Ünüvar, P. (2015). Analyzing the prosocial behaviors of pre-school children in accordance with teacher's point of view. International Journal of Social Sciences and Education Research, 1 (3), 692-698.

books were effective upon the helping and sharing behaviors of the children. Dunfield, Kuhlmeier, O'Connell and Kelley (2011) have examined the helping and sharing behaviors with 18 and 24 months old babies in their research and observed that 24 month old babies display more prosocial behaviors. So the amount of prosocial behavior increases with the age. Zsolnai, Lesznyak and Klasik (2012) have examined the aggressive and prosocial behaviors of preschoolers (16-69 months) in Hungary. In their researches, they have found out that children display prosocial behaviors towards younger kids such as helping out with daily interactions, helping out with socializing, communicating by using kind words. Senemoğlu (1994) states that the kids should have the opportunity to play freely amongst themselves without adult intervention, thus they can learn how to cooperate, decide, evaluate themselves and appreciate group interaction.

As a result of this research, the conclusion that less teacher guidance could lead to more intense interactions between kids and more positive prosocial behaviors has been drawn. In-service trainings can be given to teachers regarding the importance of regulating school activities to increase the free interaction between the children. Cross-sectional and longitudinal researches in which prosocial behaviors are examined can also be included.

\section{References}

Avcıoğlu, H. (2003). Okulöncesi dönemdeki çocuklara sosyal becerilerin öğretilmesinde işbirlikçi öğrenme yöntemi ile sunulan öğretim programının etkililiğinin incelenmesi, OMEP Dünya Konsey Toplantısı ve Konferansı Bildiri Kitabl, Ankara: Ya-pa .

Ayten, A. (2009).Prososyal davranışlarda dindarlık ve empatinin rolü. Doktora Tezi, Marmara Üniversitesi, İlahiyat Anabilim Dal1,İstanbul.

Dinç, B. ve Gültekin, M. (2003).Okulöncesi eğitimin 4-5 yaş çocuğunun sosyal gelişimine etkileri konusunda öğretmen görüşleri. OMEP Dünya Konsey Toplantısı ve Konferansı Bildiri Kitabl, Ankara: Ya-pa.

Dunfield, K., Kuhlmeier, V.A., O’Connell, L. Ve Kelley, E.(2011). Examining the Diversity of Prosocial Behavior: Helping, Sharing, and Comforting in Infancy. Infancy, 16(3), 227-247 DOI: 10.1111/j.15327078.2010.00041.x

Elo, S. Ve Kyngas, H. (2008). The qualitative content analysis process. Journal of Advanced Nursing, 62(1), 107.115

İpek, M. (2014). Prososyal davranışta liderlik tarzının rolü: Milletvekili-danışman ilişkisi üzerine bir araştırma. Yüksek Lisans Tezi. Türk Hava Kurumu Üniversitesi, Sosyal Bilimler Enstitüsü, Ankara.

Kahraman, Ö. (2012). Zihin kuramına dayalı eğitim programının 48-60 aylık çocukların bilişsel bakış açısı ve prososyal davranışlarn üzerindeki etkisinin incelenmesi. Doktora Tezi, Gazi Üniversitesi,Eğitim Bilimler Enstitüsü,Ankara.

Kakavoulis, A. (1998). Aggresive and Prosocial Behaviour in Young Greek Children, International Journal of Early Years Education,Vol.6,No.3

Özdemir, A., Koçyiğit, S., Sakin, Beceren, B., Tok, E., Güven, G., Akduman, G., Aydın, H., Tuğluk, M., Çağlak, S., Yoleri, S ve Sezer, T. (2012). Okulöncesi Eğitime Giriş, Ankara: Hedef.

Özyürek, A.ve Aydoğan,Y.(2011).Okulöncesi öğretmenlerinin serbest zaman etkinliklerine ilişkin uygulamalarının incelenmesi. Sakarya Üniversitesi Eğitim Fakültesi Dergisi, 22,41-58.

Senemoğlu, N. (1994). Okulöncesi eğitim programı hangi yeterlilikleri kazandırmalıdır?, Hacettepe Üniversitesi Eğitim Fakültesi Dergisi, 10, 21-30. 
Karoğlu, H., Ünüvar, P. (2015). Analyzing the prosocial behaviors of pre-school children in accordance with teacher's point of view. International Journal of Social Sciences and Education Research, 1 (3), 692-698.

Uzmen, S. (2001). Okulöncesi ĕ̆itim kurumlarına devam eden altı yaş çocuklarının prososyal davranışlarının resimli çocuk kitapları ile desteklenmesi. Doktora Tezi, Hacettepe Üniversitesi Sağlık Bilimler Enstitüsü, Ankara.

Yıldırım, A. ve Şimşek, H. (2011). Sosyal bilimlerde nitel araştırma yöntemleri. İstanbul: Seçkin Yayınc1lık.

Zsolnai,A.,Lesznyak,M., ve Klasik,L(2012). Pre-school children's aggressive and pro-social behaviours in stressful situations, Early Child Development and Care, 182:11, 1503-1522, DOI: $10.1080 / 03004430.2011 .623779$ 